\title{
TOLERANSI BAHAN ORGANIK PADA EFEKTIFITAS PEMAKAIAN AGENS HAYATI UNTUK MENINGKATAN PRODUKSI DAN KUALITAS KOPI ROBUSTA Di PERKEBUNAN KALIJOMPO KECAMATAN SUKORAMBI JEMBER
}

\author{
Oleh: \\ DIAN HARTATIE dan TITIEN FATIMAH *)
}

\begin{abstract}
ABSTRAK
Penelitian di laksanakan di Kalijompo. Sukorambi kabupaten Jember dengan luasan 1,6 Ha, Tahun 2007 s/d 2008 pada ketinggian tanah 640 dpl, kelembaban 85-90\% jenis tanah Inceptisol, Pusat Penelitian Kopi Kakao Se Indonesia Desa Kaliwining Kabupaten Jember, Laboratorium hama dan penyakit Fakultas Pertanian Universitas Negeri Jember.

Metode penelitian menggunakan rancangan acak kelompok 2 faktor di ulang 3 kali, dengan uji lanjutan Uji berganda DMRT dengan taraf 5\%. Adapun factor pertama (I) yaitu pemakaian bahan organic (A) dengan perlakuan : $\mathrm{A} 1=$ bekas pangkasan, $\mathrm{A} 2=$ pupuk kandang (kotoran ternak), $\mathrm{A} 3=$ bekas pangkasan/kulit kopi + jerami padi $(1: 1), \mathrm{A} 4=$ bekas pangkasan/kulit kopi + kotoran ternak $(1: 1)$. Sedangkan factor ke-dua (II) yaitu : pemakaian agen hayati (B): B1 = control, B2 = pestisida, B3 = Jamur B.bassiana (agen hayati),

B4 = Nematoda Steinernema sp (agen hayati)

Hasil tahun pertama : 1) perlakuan pemanfaatan bahan organik pada parameter pengamatan pada produksi, redemen kopi tidak memberikan pengaruh yang nyata, 2) perlakuan pemakaian hayati pada parameter pengamatan jumlah larva, jumlah imago, memberikan pengaruh yang nyata, 3) pemanfatan bahan organik (A) dan pemakaian agenhayati (B) terhadap peningkatan produksi dan kualitas kopi Robusta pada panen tahun pertama, terjadi interaksi pada parameter pengamatan tingkat serangan pada biji yang terserang hama H.hampei dan parameter jumlah biji yang terserang hama H.hampei. Dan tahun kedua diperoleh hasil penelitian: 1) bahan organik memberikan pengaruh yang nyata pada parameter tingkat serangan hama H. Hampei, 2) pPemakaian agens hayati tidak memberikan pengaruh yang nyata pada semua parameter perlakuan, 3) pemanfaatan Bahan Organik ada efektifitas pemakaian agens hayati untuk meningkatkan produksi dan kualitas kopi robusta terjadi interaksi pada parameter pengamatan produksi beras.
\end{abstract}

Kata Kunci : Bahan Organik, Agens Hayati, Produksi Kopi Robusta 



\section{PENDAHULUAN}

\subsection{Latar Belakang}

Posisi kopi Indonesia di dunia tahun 2005 , berdasarkan luas areal berada pada urutan ke 2 setelah Brazil, berdasarkan jumlah produksi berada pada urutan ke 4 setelah Brazil, Vietnam, dan Columbia, sedangkan berdasarkan volume ekspor berada pada urutan ke 4 setelah Brazil, Vietnam dan Columbia (Irawan dan Joko, 2005).

Tingkat produktifitas kopi Indonesia cukup rendah, yaitu rata-rata sebesar $700 \mathrm{~kg} / \mathrm{ha} / \mathrm{th}$, baru mencapai $60 \%$ dari potensi produktifitasnya. Sedangkan rata-rata tingkat produktifitas kopi Vietnam sebesar $1.540 \mathrm{~kg} / \mathrm{ha} / \mathrm{th}$, di Columbia mencapai $1.220 \mathrm{~kg} / \mathrm{ha} / \mathrm{th}$ dan Brazil mencapai $1.000 \mathrm{~kg} / \mathrm{ha} /$ th (Irawan dan Joko, 2005).

Salah satu sebab penurunan produksi kopi di Indonesia adalah kurangnya perawatan lahan dan frekwensi pemupukan yang menurun. Penurunan frekwensi pemupukan disebabkan karena ketidak mampuan petani membeli pupuk akibat harga yang terus menurun sehingga dosis pupuk menjadi kurang berimbang. Selain hal tersebut di atas tehnik budidaya tanaman yang belum dilaksanakan secara optimal, pasca panen yang belum dilaksanakan secara baik diantaranya pelaksanaan lelesan yang terlambat yang berakibat timbulnya masalah hama bubuk buah kopi (Hypothenemus hampei)

Mengingat adanya dampak negatif dari pengendalian dengan memakai pestisida perlu dicari pengendalian lain yaitu dengan memakai agens hayati baik memakai jamur, virus, bakteri protozoa ataupun nematoda. seperti nematode Steirnema carpocapsae dan jamur Beuveria bassiana yang dapat dipergunakan sebagai agens hayati untuk memerangi hama penting kopi Hypotenum hampei . Produksi dan kualitas kopi akan rendah jika terserang hama tersebut. Selain itu juga berakibat naiknya biaya sortasi biji cacat. Pada serangan berat mampu menurunkan produksi sekitar 40\%, karena biji berlubang dan kosong.

Untuk menghindari penurunan produksi dan mempertahankan produksi yang tinggi sesuai potensi produksi tanaman diperlukan penambahan hara ke dalam tanah dari luar dalam bentuk pupuk. Jumlah pupuk yang ditambahkan tergantung pada umur dan kondisi kesuburan tanah.
Kandungan bahan organik dalam tanah dapat ditingkatkan dengan pemberian pupuk organik baik berupa sisa tanaman, pupuk kandang

dan pupuk hijau (sisa pangkasan) dan kulit kopi yang selama ini belum dikelola dengan baik oleh petani dan perkebunan kopi padahal sangat berguna untuk meningkatkan hasil dan memperbaiki mutu kopi.

Dalam perlakuan pupuk organik dengan penambahan pupuk kandang. Ini disebabkan karena menurut Sudiarto dan Gusmani, 2004 mengatakan bahwa limbah kopi mengandung unsur $\mathrm{N}(1,88 \%), \mathrm{K}(2,04 \%), \mathrm{Ca}(0,39 \%)$ dan $\mathrm{Mg}$ $(0,39 \%)$. Sedangkan tanaman hijau (pohon pelindung) daun mengadung unsur $\mathrm{N}, \mathrm{P}_{2} \mathrm{O}_{5}, \mathrm{SiO}_{2}$ $\mathrm{CaO}, \mathrm{MgO}, \mathrm{K}_{2} \mathrm{O}$.

Pupuk kandang menurut Sudiarto dan Gusmaini (2004) mengandung unsur N, P, K , Ca dan $\mathrm{Mg}$. Sehingga gabungan perlakuan antara pupuk kandang dan bahan organik diharapkan dapat menghasilkan unsur makro dan unsur mikro yang sempurna yang sangat dibutuhan untuk meningkatkan kuantitas dan kualitas tanaman kopi.

\subsection{Rumusan Masalah}

Mengingat adanya dampak negative tersebut, maka perlu dicari alternative pengendalian yang efektif, efisien dan berwawasan lingkungan, seperti pengendalian dengan memanfaatkan agens hayati serta toleransinya bahan organik untuk meningkatkan produksi dan kualitas kopi Robusta.khususnya dikebun kopi Kalijompo kecamatan Sukorambi serta petani kopi di kabupaten Jember umumnya.

Pemilihan komoditi kopi dalam penelitian disebabkan tanaman kopi cukup potensial untuk dikembangkan di daerah Jember. Karena potensinya tersebut, pengusahaan kopi tidak hanya dikelola oleh perkebunan rakyat, tetapi juga dikelola oleh pihak BUMN (PT. Perkebunan XII), Perusahaan Daerah Perkebunan (PDP), dan swasta. Total perkebunan kopi di Jember 16.882 ha dengan pengusahaan kopi rakyat seluas 4.911 ha yang tersebar di 27 kecamatan dengan areal terluas di Kecamatan Silo. Selanjutnyan 14 kebun dilelola PT. Perkebuan XII (6.009 ha), 7 kebun seluas 2-22267 ha (PDP) dan 10 kebun seluas 3.695 dikelola oleh swasta (Anonim, 2004b). 


\section{TUJUAN DAN MANFAAT}

Penelitian ini untuk mengetahui toleransi pemanfaatan bahan organic dan efektifitas pemakaian agens hayati terhadap produksi dan kualitas kopi robusta dinkebun Kalijompo.

Banyaknya limbah kopi yang terbuang yaitu bekas pangkasan kopi dan bahan organic di sekitar tanaman/areal perkebunan yaitu kotoran kambing, jerami padi.

Adanya hama penting kopi Hypothenemus hampei yang sering mengganggu tanaman kopi diperkebunan Kalijompo khususnya. Agar kopi dapat berproduksi optimal dan berkualitas ekspor serta dapat terhindar dari hama tersebut, sekaligus mengingat pestisida yang begitu beresiko negative (adanya residu), maka dengan pengendalian cara hayati dengan pemakaian entopathogen seperti agens hayati jamur Beauveria bassiana, nematoda Steinernema carpocapsae yang sudah teruji virulensinya diharapkan dapat menekan serangan hama tersebut.

\section{METODOLOGI PENELITIAN}

Penelitian ini di laksanakan di Kebun kalijompo. dengan luasan 1,6 Ha di kecamatan Sukorambi kabupaten Jember, ketinggian tanah 640 dpl, kelembaban $85-90 \%$ dengan jenis tanah Inceptisol, Pusat Penelitian Kopi Kakao Se Indonesia Desa Kaliwining Kabupaten Jember, Laboratorium hama dan penyakit Fakultas Pertanian Universitas Negeri Jember.

Dipergunakannya agen hayati karena hama H.hampei berada di dalam buah, sehingga sangat sulit dikendalikan. Juga karena tuntutan konsumen kopi yang menetapkan pesyaratan mutu, ambang residu serta proses produksi yang ramah lingkungan..

Penelitian dilaksanakan dengan dua tahap, tahun pertama (I) di mulai bulan Maret s/d April 2008 pengeplotan lahan perkebunan sebagai areal/lahan yang endemic serangan hama bubuk buah kopi (H. hampei), juga pemberian perlakuan Bahan organic. Pada bulan April s/d Juni 2008 untuk persiapan agen hayati (pengembangbiakan) di laboratorium hama dan penyakit UNEJ serta di lanjutkan pengaplikasian agen hayati ke pertanaman kopi sesuai perlakukan. Selanjutnya bulan Agustus 2008 dilaksanakan pengamatan pedahuluan untuk tahun pertama. Panen kopi pada tahun pertama pada bulan Agustus s/d Oktober 2008.
Tahun berikutnya yaitu tahun ke-dua (II) bulan Januari s/ April 2009 untuk memperlakukan tanaman dengan bahan organic, karena pada bulan Januari s/d April pemangkasan pengaturan biasa dilakukan di kebun kopi Kalijompo. Persiapan agen hayati bulan April s/d Mei 2009 selanjutnya dilakukan penyemprotan agen hayati ke pertanaman kopi sesuai perlakuan, dan selanjutnya bulan Mei 2009 dilakukan pengamatan pendahuluan sebelum aplikasi agenhayati. Panen kopi tahun ke-dua Agustus s/d Oktober 2009.

Bahan dan Alat

Bahan : Tanaman kopi; agen hayati : jamur B.bassiana dan nematode entomopatogen (NEP) Steinernema sp, bahan organic : limbah kopi (bekas pangkasan), kotoran kambing ; pestisida ; pupuk an organic (Urea, SP 36, KCl).

Alat : Sprayer, seperangkat alat pengembang biakan jamur B.bassiana dan seperangkat alat pengembang biakan nematoda entomopatogen (NEP) Steinernema sp, cangkul, Petridis, alat pembesar : mikroskop dan loupe, alat tulis dan lainnya yang berhubungan dengan penelitian ini.

\section{Metode Analisis}

Metode penelitian menggunakan rancangan acak kelompok dengan 2 faktor di ulang 3 kali. Adapun factor pertama (I) yaitu pemakaian bahan organic (A) dengan perlakuan :

A1 = bekas pangkasan

A2 = pupuk kandang (kotoran ternak)

A3 = bekas pangkasan/kulit kopi + jerami padi $(1: 1)$

A4 = bekas pangkasan/kulit kopi + kotoran ternak $(1: 1)$

Sedangkan factor ke-dua (II) yaitu : pemakaian agen hayati (B)

$\mathrm{B} 1=$ kontrol

$\mathrm{B} 2=$ pestisida

B3 = Jamur B.bassiana (agen hayati)

$\mathrm{B} 4=$ Nematoda Steinernema $\mathrm{sp}$ (agen hayati)

Model Rancangan Penelitian di lapang adalah :

$$
\mathrm{Y}_{\mathrm{iijk}}=\mathrm{u}+\mathrm{K}_{\mathrm{k}}+\mathrm{A}_{\mathrm{i}}
$$

Perlakuan yang berbeda nyata pada penelitian dilanjutkan Uji berganda DMRT dengan taraf 5\% (Kwanchai dan A.Gomez, 1995). Yaitu; Uji $\operatorname{DMRT}(Ә)=\operatorname{SSR}(Ә) \times \mathrm{d}$ 


\title{
IV. HASIL DAN PEMBAHASAN
}

\author{
4.1 Hasil Analisis
}

Tabel 4.1 Rangkuman Anova Toleransi Bahan Organik Pada Efektifitas Pemakaian Agens Hayati Untuk Meningkatkan Produksi dan Kualitas Kopi Robusta di Kebun Kalijompo Kecamatan Sukorambi Jember

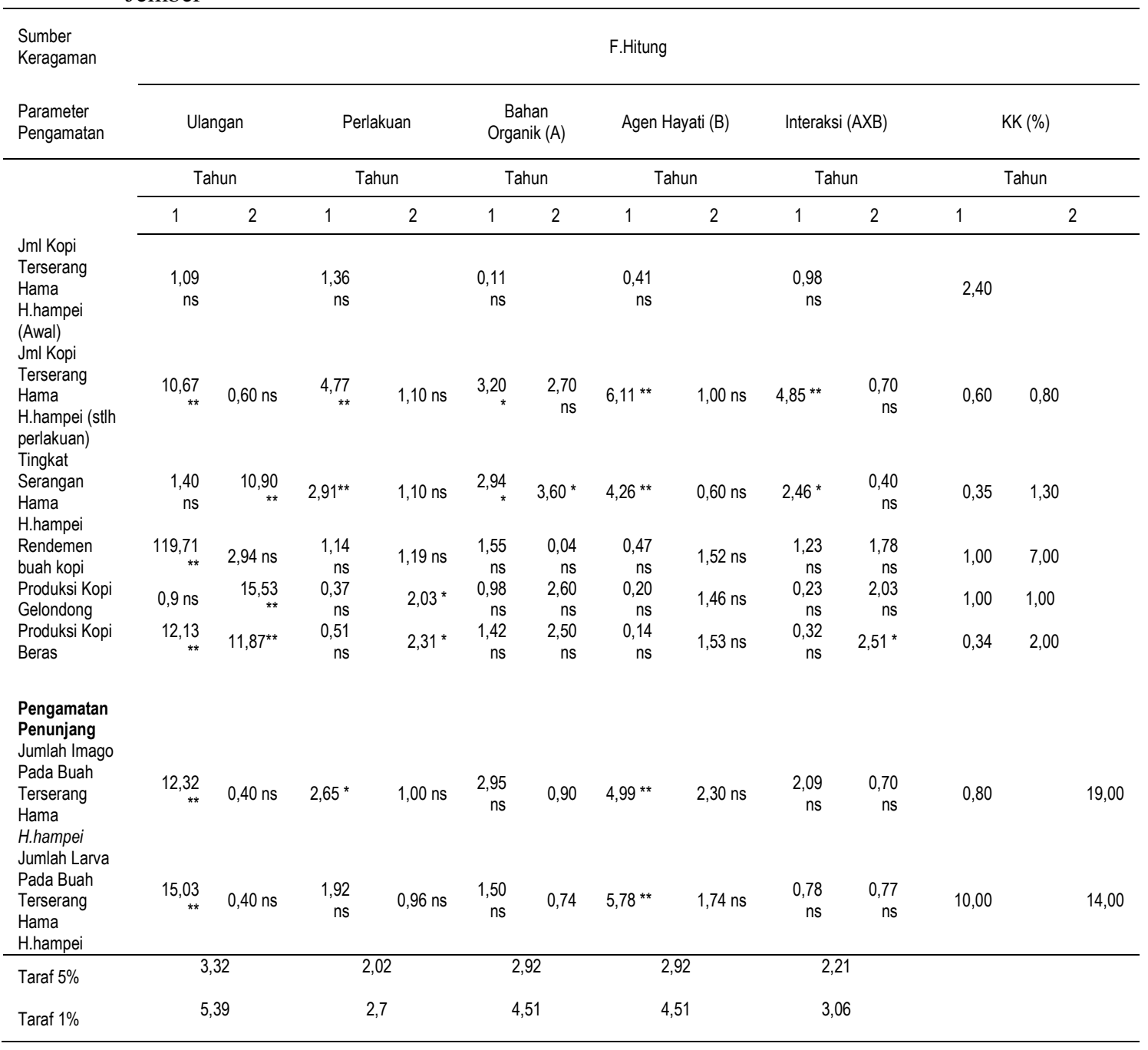

Tabel 4.2 Uji DMRT 5\% Terhadap Jumlah Larva Pada Biji Terserang Hama H.hampei Pada Perlakuan Pemakaian Agen hayati Pada Tahun Pertama

\begin{tabular}{lrrrrr} 
Perlakuan & \multicolumn{1}{l}{ Nilai } & \multicolumn{2}{c}{ Taraf } & \multicolumn{2}{c}{ Notasi } \\
Perlakuan & Rata-rata & LSR 5\% & LSR 1\% & $5 \%$ & $1 \%$ \\
\hline B3 & 265,83 & & & a & a \\
B4 & 338,83 & 216,3958 & 291,3 & a & a \\
B2 & 585,17 & 227,6274 & 304,0 & b & ab \\
B1 & 630,83 & 233,6176 & 311,5 & b & b \\
\hline
\end{tabular}

Keterangan: Angka-angka yang diikuti oleh huruf yang sama pada factor yang sama menunjukkan tidak berbedanyata berdasarkan uji DMRT 
Dian Hartatie dan Titin Fatimah, Toleransi Bahan Organik Pada Efektifitas Pemakaian Agens Hayati Untuk Meningkatkan Produksi Dan Kualitas Kopi Robusta Di Perkebunan Kalijompo Kecamatan Sukorambi

Tabel 4.3 Uji DMRT 5\% Terhadap Jumlah Imago Pada Biji Terserang Hama H.hampei Pada Perlakuan Pemanfaatan Bahan Organik Tahun Pertama

\begin{tabular}{llccccc}
\hline Perlakuan & Nilai & \multicolumn{2}{c}{ Taraf } & \multicolumn{3}{c}{ Notasi } \\
& Rata-rata & & LSR 5\% & \multicolumn{2}{c}{ LSR1\% } & \multicolumn{2}{c}{$5 \%$} & a \\
\hline A1 & 474,3 & & & a \\
A4 & 618,3 & 120,3 & 161,9 & b & ab \\
A2 & 619,5 & 126,6 & 169,0 & b & b \\
A3 & & 129,9 & 173,2 & c & c \\
\hline
\end{tabular}

Keterangan : Angka-angka yang diikuti oleh huruf yang sama pada factor yang sama menunjukkan tidak berbedanyata berdasarkan uji DMRT

Tabel 4.4 Uji DMRT 5\% Terhadap Jumlah Imago Pada Biji Terserang Hama H.hampei Pada Perlakuan Pemakaian Agenhayati tahun Pertama

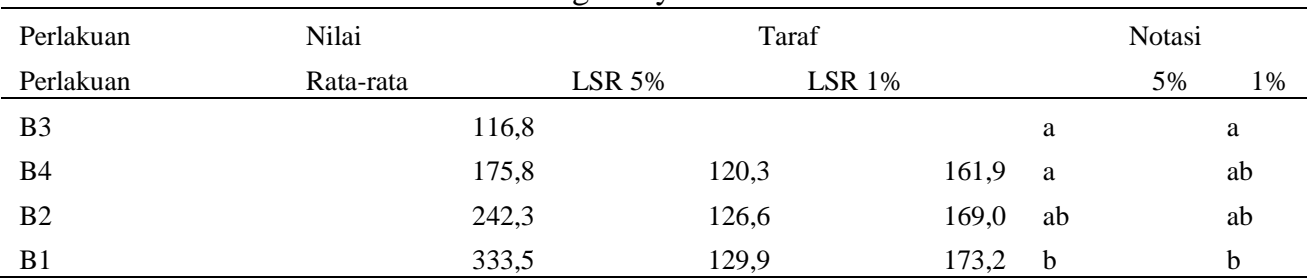

Keterangan : Angka-angka yang diikuti oleh huruf yang sama pada factor yang sama menunjukkan tidak berbedanyata berdasarkan uji DMRT

Tabel 4.5 Uji DMRT 5\% Toleransi Bahan Organik terhadap pemakaian Agenhayati pada Parameter Pengamatan Jumlah Buah Kopi Yang Terserang Hama H.hampei Pada Tanaman Kopi Setelah Perlakuan

\begin{tabular}{lccccc}
\hline Perlakuan & Nilai & LSR5\% & LSR1\% & \multicolumn{2}{c}{ Notasi } \\
& Rata-rata & & & $5 \%$ & $1 \%$ \\
\hline A3B3 & 94 & & & $\mathrm{a}$ & $\mathrm{a}$ \\
A4B3 & 128 & 219 & 294 & $\mathrm{ab}$ & $\mathrm{a}$ \\
A1B1 & 146 & 230 & 307 & $\mathrm{ab}$ & $\mathrm{a}$ \\
A2B4 & 156 & 236 & 315 & $\mathrm{ab}$ & $\mathrm{a}$ \\
A4B4 & 167 & $\mathbf{2 4 2}$ & $\mathbf{3 1 9}$ & $\mathrm{ab}$ & $\mathrm{a}$ \\
A1B3 & 171 & 246 & 327 & $\mathrm{ab}$ & $\mathrm{a}$ \\
A1B4 & 175 & 249 & 330 & $\mathrm{ab}$ & $\mathrm{a}$ \\
A3B2 & 183 & 251 & 334 & $\mathrm{ab}$ & $\mathrm{a}$ \\
A2B3 & 191 & 254 & 337 & $\mathrm{ab}$ & $\mathrm{a}$ \\
A2B1 & 207 & 255 & 339 & $\mathrm{ab}$ & $\mathrm{a}$ \\
A2B2 & 241 & $\mathbf{2 5 6}$ & $\mathbf{3 4 1}$ & $\mathrm{b}$ & $\mathrm{a}$ \\
A3B4 & 257 & 344 & $\mathrm{~b}$ & $\mathrm{a}$ \\
A4B1 & 245 & 258 & 345 & $\mathrm{~b}$ & $\mathrm{a}$ \\
A1B2 & 270 & 260 & 347 & $\mathrm{~b}$ & $\mathrm{a}$ \\
A4B2 & 277 & 260 & 347 & $\mathrm{~b}$ & $\mathrm{a}$ \\
A3B1 & 284 & 260 & 349 & $\mathrm{c}$ & $\mathrm{b}$ \\
\hline Keterang & & & & \\
\end{tabular}

Keterangan : Angka-angka yang diikuti oleh huruf yang sama pada factor yang sama menunjukkan tidak berbedanyata berdasarkan uji DMRT 
Tabel 4.6 Uji DMRT 5\% Toleransi Bahan Organik terhadap pemakaian Agenhayati pada Parameter Tingkat Serangan Hama H.hampei Pada Tanaman Kopi Setelah Perlakuan

\begin{tabular}{|c|c|c|c|}
\hline Perlakuan & $\begin{array}{l}\text { Nilai } \\
\text { Rata-rata }\end{array}$ & $\begin{array}{l}\text { LSR } \\
5 \%\end{array}$ & Notasi \\
\hline A1B1 & 3,500 & & a \\
\hline $\mathrm{A} 1 \mathrm{~B} 2$ & 6,900 & 13,6 & $\mathrm{a}$ \\
\hline A1B3 & 6,900 & 14,3 & $\mathrm{a}$ \\
\hline A1B4 & 7,300 & 14,6 & $a b$ \\
\hline A2B1 & 7,800 & 15,0 & $a b$ \\
\hline $\mathrm{A} 2 \mathrm{~B} 2$ & 8,100 & 15,2 & $a b$ \\
\hline A2B3 & 8,500 & 15,4 & $a b$ \\
\hline A2B 4 & 9,000 & 15,6 & $a b$ \\
\hline $\mathrm{A} 3 \mathrm{~B} 2$ & 9,100 & 15,7 & $a b$ \\
\hline A3B 1 & 9,700 & 15,8 & $a b$ \\
\hline A3B3 & 9,900 & 15,9 & $a b$ \\
\hline A3B 4 & 11,200 & 15,9 & $\mathrm{ab}$ \\
\hline A4B1 & 12,400 & 16,0 & $a b$ \\
\hline A4B2 & 13,900 & 16,1 & $a b$ \\
\hline A4B3 & 16,600 & 16,1 & $a b$ \\
\hline A4B4 & 21,800 & 16,1 & $\mathrm{~b}$ \\
\hline
\end{tabular}

Keterangan : Angka-angka yang diikuti oleh huruf yang sama pada factor yang sama menunjukkan tidak berbedanyata berdasarkan uji DMRT

\subsection{Pembahasan}

\section{a. Jumlah Kopi yang tergerek Bubuk Buah}

\section{Setelah Perlakuan}

Salah satu faktor dominan yang menyebabkan rendahnya kualitas produksi dan kuantitas buah kopi adalah gangguan hama penggerek buah kopi $H$. hampei. Serangan ini dapat menimbulkan kehilangan produksi sampai $10 \%$ pada buah muda dan $40 \%$ pada buah kopi yang sudah tua (Anonim, 1989)

Serangan H. hampei pada buah kopi menyebabkan buah kopi berlubang , cacat dan rusak sehingga kwalitas menurun (Anonim, 1992).

Pada lampiran tabel 38 dan pada tabel 5.1 menunjukkan bahwa jumlah kopi yang terserang $H$. hampei baik pada perlakuan $\mathrm{A}$ (bahan organik) maupun perlakuan B ( agens hayati) , ataupun faktor interaksinya tidak menunjukkan pengaruh yang nyata. Ini berarti perlakuan A dan B tidak berpengaruh secara nyata terhadap jumlah kopi yang berlubang.

Menurut Suwarso,D.1.H 1997 faktor-faktor yang mempengaruhi perkembangan hama bubuk buah $H$. hampei adalah faktor makanan dan lingkungan. Sedangkan hasil pengamatan di lapang menunjukkan bahwa kehidupan hama bubuk buah H. hampei dalam hidupnya pada buah kopi hidup dengan bergerombol membentuk koloni-koloni. Hama ini tumbuh dan berkembang biak pada tempat-tempat tertentu yang sangat disukai. Sedangkan pada tempat (buah lain) hanya sebatas sebagai tempat untuk mencari makan Diduga meskipun buahnya sedikit tetapi buah tersebut sangat potensiil untuk tumbuh dan berkembangbiaknya hama, tetapi pada buah kopi yang lebat tetapi buah tersebut kurang cocok sebagai tempat berkembang biaknya hama . Sehingga apabila diuji hasil tidak menunjukkan beda nyata.

\section{b. Tingkat Serangan}

Pada lampiran tabel 44 menunjukkan bahwa factor perlakuan A menunjukkan perbedaan pengaruh yang nyata sedangkan factor B tidak berbeda nyata.Paa lampiran tabel 43 menunjukkkan bahwa tingkat serangan $H$. hampei pada buah kopi di Perkebunan Kalijompo berkisar 0,34\%-4,11\%. Tingkat ini tergolong ringan. Hal ini sesuai dengan pendapat Suwarso, 1997 yang menyatakatan bahwa tingkat kerusakan ringan akibat serangan $H$. hampei pada buah kopi apabila berkisar 0-25\%. Tingkat kerusakan rendah diperoleh pada Perlakuan A1 diikuti A2, A3 dan A4.

Menurut Anonim, 2001, tanaman kopi memerlukan struktur tanah yang baik dengan kadar 
bahan organik minimal 3\%. Hasil analisa Laboratorium Tanah Politeknik menunjukkan bahwa kandungan bahan oganik pada A1 sebesar 3,65 dan N, P, K yang lebih rendah dari A2, A3 dan A4 sudah cukup memenuhi kebutuhan tanaman kopi.

Hama bubuk buah $H$. hampei hanya hidup tumbuh dan berkembang biak pada buah-buah dengan kekerasan tertentu. Hama ini hidup secara bergerombol pada tempat-tempat tertentu secarabersama-sama. Hanya buah-buah tertentu yang sangat disenangi sebagai tempat berkembang biak. Tempat yang lain (buah yang lain) hanya dipakai sebagai makanan (hanya digerek sehinggan kerusakan ringan (skor 1dan 2) Ini menyebabkan kondisi kelebatan buah tidak berpengaruh nyata terhadap pertumbuhan dan perkembangan Hama bubuk buah $H$. hampei tetapi peran iklim mikro yang sangat dominant bagi perkembangan hama.

\section{c. Produksi Kopi Glondong}

Pada lampiran tabel 7 menunjukkan bahwa pengamatan produksi kopi glondong pada perlakuan A, perlakuan B serta Interaksi perlakuan AB tidak menunjukkan perbedaan yang nyata terhadap kopi glondong.

Menurut Najiyati, 1995 kopi termasuk tanaman hari pendek, dimana waktu yang dibutuhkan sejak bunga mekar sampai menjadi buah untuk kopi Robusta berkisar 11-12 bulan. Selain dipengaruhi moleh fotoperiodisme, faktor lain yang dapat mempengaruhi pembentukan bakal bunga adalah intensitas cahaya, perbedaan suhu siang dan malam, curah hujan, serta varietas atau klon.

Selain faktor yang disebutkan di atas ada faktor yang sangat menentukan produksi kopi adalah kecukupan kandungan unsur sebagai media tanam serta keberadaan hama utama yang menyerang tanaman kopi. Hasil analisis tanah di laboratorium tanah Politeknik , tahun 2009 menunjukkan bahwa kandungan bahan organik, Urea, SP36 dan $\mathrm{KCl}$ pada A1, A2, A3 dan A4 menunjukkan urutan yang terus meningkat. Ini kemungkinan pada perlakuan A1 kebutuhan unsur hara sudah tercukupi karena kopi dapat tumbuh pada media tanam dengan bahan organik minimal $3 \%$. Sehingga penambahan bahan organik dan penambahan unsure hara lain tidak pada meningkatkan produksi kopi glondong secara nyata.

Menurut Anonim , 2001 Hama bubuk buah $H$. hampei tidak hanya menyebakan rendahnya produksi, tetapi juga memerosotkan mutu kopi . Serangga ini menggerek buah kopi yang masih muda, juga buah yang telah masak. Gejala serangan pada buah kopi yang muda mengakibatkan buah berwarna kuning, mengalami pembusukan dan gugur. Hal ini diduga banyak kopi yang terserang pada saat muda dan gugur sehingga tidak sampai terpetik. Ini mengakibatkan hasil tidak berbeda nyata. Ada pohon kopi dalam perlakuan yang berbuah banyak tetapi banyak yang terserang pada saat muda sehingga banyak yang gugur pada saat dipanen. Ataupun sebaliknya buah tidak lebat tetapi tidak ada yang gugur. Oleh karena itu hasil dalam perlakuan tidak menunjukkan perbedaan pengaruh yang nyata.

\section{d. Produksi Kopi Beras}

Pada lampiran tabel 19 menunjukkan bahwa pada pengamatan kopi beras tidak menunjukkan perbedaan pengaruh yang nyata pada perlakuan A, dan B , tetapi terjadi interaksi pada perlakuan A dan B. Produksi suatu tanaman dipengaruhi baik oleh faktor dalam ataupu faktor luar. Faktor luar meliputi : kelembaban, temperatur, suhu, kesuburan tanah dan serangan hama dan penyakit. Media tanam tanaman kopi yang cukup tersedia unsur hara pada pertumbuhannya, tanaman akan tumbuh optimal, sehingga tanaman lebih tahan terhadap lingkungan yang kurang menguntungkan, juga diharapkan lebih tahan terhadap serangan dari hama dan penyakit. Sehingga tanaman akan berproduksi lebih baik.

Produksi kopi beras sangat dipengaruhi oleh produksi kopi glondong. Produksi kopi glondong juga menunjukkan beda nyata. Ini secara langsung mempengaruhi produksi kopi beras .

Sifat hidup dari hama bubuk buah $H$. hampei adalah bergerombol. Ada blok-blok dalam perlakuan yang sangat disukai untuk tempat berkembang biak $H$. hampei sedangkan pada blokblok tersebut B. bassiana dan Nematoda tidak dapat hidup dengan baik karena naungan kurang sehingga tidak dapat hidup dan berkembang dengan baik.

Menurut Nursidik, 1992, kelembaban relatif yang diperlukan bagi perkembangan $B$. bassiana dan Nematoda adalah 80-100\%. Pertumbuhan spora optimum bagi perkembangan sporran B. bassiana adalah $92 \%$.

Faktor pemberian insektisida juga tidak berpenbgaruh secara nyata. Hal ini disebabkan hama $H$. hampei hidup dalam buah kopi. Ini yang menyebabkan hama ini sulit ditembus oleh bahanbahan yang diaplikasikan pada buah kopi

\section{e. Rendemen Biji}

Pada lampiran tabel 13 menunjukkan perlakuan A dan perlakuan B tidak menunjukkan beda nyata pada pengamatan rendemen kopi, tetapi terjadi interaksi antara perlakuan A dan B. 
Dian Hartatie dan Titin Fatimah, Toleransi Bahan Organik Pada Efektifitas Pemakaian Agens Hayati Untuk Meningkatkan Produksi Dan Kualitas Kopi Robusta Di Perkebunan Kalijompo Kecamatan Sukorambi

Rendemen biji kopi adalah persentase rasio berat biji kopi kering dibandingkan dengan berat kopi glondong. Rendemen biji kopi ini erat hubungannya dengan produksi kopi suatu perkebunan. Makin tinggi rendemen biji kopi kering maka makin tinggi produktifitas kebun yang bersangkutan, demikian sebaliknya. Akibat serangan H . hampei , maka biji kopi berlubang dan apabila tingkat serangan tinggi maka mengakibatkan biji keropos bahkan hancur pada saat penggerbusan.

\section{Pengamatan Penunjang}

\section{a. Jumlah Imago}

Pada lampiran tabel 32 dan tabel ringkasan hasil penelitian menunjukkan bahwa faktor perlakuan A tidak berbeda nyata pada pengamatan jumlah imago pada buah kopi . Faktor B menunjukkan pengaruh tidak berbeda nyata pada pengamatan jumlah imago. Tidak terjadi interaksi antara perlakuan A dan perlakuan B.

Sifat hidup dari hama bubuk buah $H$. hampei adalah bergerombol. Ada blok-blok dalam perlakuan yang sangat disukai untuk tempat berkembang biak $H$. hampei sedangkan pada blokblok tersebut B. bassiana dan Nematoda tidak dapat hidup dengan baik karena naungan kurang sehingga tidak dapat hidup dan berkembang dengan baik. Selain hal tersebut tidak semua buah kopi dipergunakan sebagai tempat berkembang biak hama bubuk buah $H$. hampei . Hama bubuk buah $H$. hampei hanya berkembang biak pada buah-buah tertentu, buah yang lain hanya sebagai pakan. Tempat yang lebih subur belum tentu lebih disukai apabila lingkungan (iklim mikro) disitu kurang mendukung bagi perkembangan hama tersebut.

\section{VI .KESIMPULAN DAN SARAN}

\subsection{Kesimpulan}

Dari hasil penelitian tahun pertama ini dapat diperoleh suatu kesimpulan

a. Bahan organik memberikan pengaruh yang nyata pada parameter tingkat serangan hama H. Hampei

b. Pemakaian agens hayati tidak memberikan pengaruh yang nyata pada semua parameter perlakuan,

c. Pemanfaatan Bahan Organik Pada Efektifitas pemakaian Agens Hayati Untuk Meningkatkan Produksi dan Kualitas Kopi Robusta terjadi interaksi pada parameter pengamatan produksi beras.
Menurut Nursidik, 1992, beberapa faktor yang dapat menghambat perkembangan B. bassiana diantaranya kelembaban. Kelembaban relatif yang diperlukan bagi perkembangan $B$. bassiana dan Nematoda adalah 80-100\%. Pertumbuhan spora optimum bagi perkembangan sporran B. bassiana adalah $92 \%$. Suhu optimum untuk perkembangan $B$ - bassiana adalah $23^{\circ} \mathrm{C}-25^{\circ} \mathrm{C}$. Kelembaban yang terdapat di Perkebunan Kalijompo pada saat penelitian kurang $80 \%$ sehingga $B$. bassiana kurang dapat berkembang.

Faktor pemberian insektisida yang berpengaruh tidak nyata pada pengamatan. Ini diduga pada saat aplikasi tidak tepat sasaran . Hal ini disebabkan hama bubuk buah H. hampei hidup di dalam lipatan-lipatan buah . Hama tidak keluar dari lubang gerekan karena makanan sudah tersedia di dalam Hama jantan yang ke luar pada sore hari untuk kawin , tetapi hama betina hidup di dalam buah kopi tidak keluar karena makanan sudah tersedia di dalam.

\section{b. Jumlah Larva}

Pada lampiran tabel 26 dan tabel 5.1 hasil penelitian menunjukkan bahwa baik perlakuan A, perlakuan $\mathrm{B}$ maupun $\mathrm{AB}$ tidak menunjukkan hasil yang berbeda nyata pada pengamatan jumlah larva .Keberhasilan pertumbuhan dan perkembangan hama bubuk buah $H$. hampei lebih ditentukan oleh unsur hara mikro dan keberadaan hama yang sulit untuk ditembus mengakibatkaan semua perlakuan menunjukkan tidak berbeda secara nyata.

Hal lain yang sangat mempengaruhi dalam pengamatan hasil penelitian adalah banyak buah kopi yang gugur sebelum dipanen dan kurang telitinya pekerja dalam memanen. Ini yang menyebabkan kurang telitinya hasil penelitian.

\subsection{Saran}

Untuk mengetahui toleransi dari pemanfatan bahan organik dan efektifitas pemakaian agenhayati uuntuk meningkatkan produksi dan kualitas dari kopi Robusta di Kebun Kalijompo Kecamatan Sukorambi Jember, perlu di teruskan selama 2 tahun lagi, tahun ke tiga, dan ke empat. Sehingga hasilnya dapat dimanfaatkan untuk direkomendasikan toleransi tersebut pada perkebunan kopi Kalijompo. 


\section{DAFTAR PUSTAKA}

Abbott W.S. 1925. A. Method of Coutting the Effectiveness of on Insecticide.J.Econ. Entomol. 18:265-267

Anonim. 1989.Pengendalian Hama Bubuk Buah pada Kopi. Trubus 25 Pebruari 1989.

Anonim. 1992. Hadapi Kopi dengan Cendawan. Pedoman Rakyat 6 Oktober 1991.

Anonim. 2001. Using Beauveria bassiana for Insect Management . UCONN IPM. Integrated Pest Management : General Biological Controls Beauveria bassiana htt:// www. Uconn: edujipm/general/htms/bassinia.htm. April 16. 2001.

Anonim. 2004a. Jamur Insektisida Biologi Yang Ramah Lingkungan. Htt ://www. Pikiran Rakyat. Com/Cetak/u.464/5/Penelitian.htm.

Anonim. 2004b. Pembangunan Kabupaten Jember

Anonim. 2004c. Kopi Organik. Dinas Perkebunan Pemerintah Sumatra Barat.http/www Sumbarprd go ud/perkeb.

Anonim. 2004a. Jamur Insektisida Biologi yang Ramah Lingkungan. http://www.pikiran rakyat.comcetaku4645penelitian.htm.3p

Anonim. 2004b. Eksportir Kopi Jawa Timur dihimbau Penuhi Syarat Jepang dalam Kompas, Kamis 02 Oktober.2004.

Badan Pusat Statistik, 2002, Kabupaten Jember dalam Rangka Tahun 2002

Balai Proteksi Tanaman Perkebunan. 2007. JUKLAK/JUKNIS Pengembangan Agens Hayati Di Tingkat Petani Tahun 2007 dalam Kegiatan Pengembangan PHT Tanaman Perkebunan. JawaBarat: Balai Proteksi Tanaman Perkebunan

Baon.J.B, R. Sukasih, Nurkolis dan S. Sutanto. 2000. Role of Inorganic and Bio-Aktivator and Raw Material Composition in The Rate of Decomposition and Quality of CoffeeShell Chompost. Paper Presented at The International Conggres and Symposium on South East Asian Agricultural Sciences. Bogor. Indonesia.
Dinas Pertanahan, 2002, Kondisi Tanah Jember

Daud Husni. 1997. Pedoman Pengelolaan Budidaya Kopi Robusta. : Surabaya. PTP XII.

Ehlers and Peters. 1995. Current and Future Use of Nematodes in BioKontrol. In Practise and Commersial Aspects with Regards to Regulator Policy Issues. Biocontr.Sci Technol.

Erwiyono,R; A. Wibawa, Baon. Abdullah,S. 2000. Pengaruh Sumber Bahan Organik Terhadap Keefektifan Pemupukan Kompos pada Kakao dan Kopi. Warta Pusat Penelitian Kopi dan Kakao Indonesia. 16. 45-49.

Eswaran.H, S.M. Virmani \& L.D. Spivey. 1993. Substainable Agriculture in Developing Countries: Contraints, Chalanges, and Choices. In Ragland \& R. Lal (Eds) Technologgies for Sustainable Agriculture In The Tropics. ASA Spec. Pup. No 56. ASA-CSSA. Medison.WI.

Gabriel G. B.P dan Riyanto. 1989. Microbial Control to Insect Pest Management National State Crop Protection Project. Directorat General of State. Jakarta.

Hakim,N. a 2004. AEKI Ingatkan Eksportir Soal Residu Pestisida. Jendela Informasi Perkopian. Edisi 123/Th XI/ NopemberDesember 2004.

Hakim,N. b. 2004.Kopi Indonesia Perlu Diselamatkan. . Jendela Informasi Perkopian. Edisi 122/Th XI/SeptemberOktober 2004.

Irawan G dan Joko. 2005. Kopi Tetap Jadi Andalan Ekspor http://www.Sinar Harapan Cord/Ekonomi/2005/0323/prun. html.3p.

Lia. 2004. Masih Fluktuatif Harga Kopi Dunia. Kompas 19 Juli 2004.

Laba,I.W.2001. Keanekaragaman Haayati Antrophoda dan Peranan Musuh Alami Hama Utama Padi pada Ekosistim Sawah. IPB Bogor. Htt:66.2987/255/searh/each?p= 
Dian Hartatie dan Titin Fatimah, Toleransi Bahan Organik Pada Efektifitas Pemakaian Agens Hayati Untuk Meningkatkan Produksi Dan Kualitas Kopi Robusta Di Perkebunan Kalijompo Kecamatan Sukorambi

pengelolaan + hama + terpadu + padi + jagung+kedelai cide....10/04.12p.

Mawardi, S a. 2004. Mulai Ada Terobosan Hindari Pupuk Kimia dan Mawardi, S b. 2004. Perbaikan Mutu Kopi Mendesak Dilakukan. Pestisida. Kopi Indonesia. Jendela Informasi Perkopian. Edisi 123/Th XI/ Nopember-Desember 2004.

Mawardi, S b. 2004. Kopi Organik dan Spesial Solusi Atasi krisis Kopi. Kopi Indonesia. Jendela Informasi Perkopian. Edisi 123/Th XI/ Nopember-Desember 2004.

Natawigena,H dan N, Susniathi. 1987. Hama-hama Tanaman Perkebunan Rakyat dan Cara Pengendalian Progam Pendidikan (SO-1). Proteksi Tanaman Perkebunan Fakultas Pertanian Universitas Padjajaran Bandung.

Pujiyanto. 1996. Status Bahan Organik Tanah pada Perkebunan Kopi dan Kakao di Jawa Timur. Warta Puslit Kopi Kakao. 12.

Rubio,S, Guntoro dan Suprapto. 2004. Usahatani Kopi Robusta Dengan Pemanfaatan Kotoran Kambing Sebagai Pupuk Organik Di Bali. Jurnal Pengkajian dan Pengembangan Teknologi Pertanian Vol.6. No.1 Januari 2003.

Suharto, Trisusilowati E.B, Purnomo,H. 1998. Kajian Asdpek Fisiologik Beauveria bassiana dan Virulensinya Terhadap Helicoverpa armigera Jurnal Perlindungan Tanaman Indonesia. Vol 4(2), 45-56.

Kwanchai dan A Gomez. 1995. Prosedur Statistik Untuk Penelitian Pertanian Edisi Kedua Universitas Indonesia (UI-Press). 698 hal.

Nursidik, 1992. Hadapi HAma Bubuk Buah Kopi dengan Cendawan dalam Warta AEKI, Nopember 1992

Rubiyanto. 2003. Usaha Tani Kopi Robusta dengan Pemanfaatan Kotoran Kambing Sebagai Pupuk Organik di Bali. Jurnal Pengkajian dan Pengembangan Teknologi Pertanian Vol.6 No.1 Januari 2003: 73-80

Rudy dkk. 2000. Pengaruh Sumber bahan Organik Terhadap Keefektifan Pemupukan Kompos pada kakao dan Kopi. Warta Pusat Penelitian Kopi dan kakao Indonesia. 16(1), p 45-49
Sudiarto dan Gusmaini. 2004. Pemanfaatan Bahan Organik In Situ Untuk Efisiensi Budidaya jahe Yang Berkelanjutan. Jurnal Litbang Pertanian. 33(2).Bogor.

Najiyati, S. 1995. Kopi Budidaya dan Penangnan Lepas Panen. Jakarta. Penebar Swadaya.192 hal.

Suwarso,D.L.H. 1997. Perilaku dan Siklus idup dari hama Bubuk Buah Kopi (H.h.hampei). Departemen Pendidikan dan Kebudayaan Reprublik Indonesia UNEJ. 41 hal.

Srikamto. 2006.Teknik Perbanyakan dan Aplikasi Jamur B.bassiana. Puslit Jember.

Sulistyo,D.1998.Bioinsektisida Baru Nematoda Entomopatogen dalam Konsep Pertanian Yang berwawasan Lingkungan. Dalam Makalah Seminar Tenaga Pengajar Fakultas Pertanian Universitas Jember. Maret 1998.

Sulistyo, D. 2006. Pemanfaatan Nematoda Entomopatogen, Sternerma sp dan Heterorhabditis sp. Isolat Lokal Sebagai Agenhayati Pengendalian Hama Hortikultura.

Simanjuntak. 202. Musuh Alami hama dan Penyakit Tanaman Kopi. Jakarta: Direktorat Perlindungan Perkebunan. Direktorat Jendral Bina Produksi Perkebunan Departemen Pertanian

Sudarmadji. 1997. Optimalisasi Pemanfaatan B.bassiana, Bals(Vuill). Untuk Pengendalian Hama. Balai Penelitian Getas, Salatiga. P 5

Untung, K.2001. Pengantar Pengelolaan Hama Terpadu. Yoyakarta. Gajah mada. University Press.

Wrigley, G.1998. Coffee.New York. Copublished in The United States with John Wiley \& Sons Inc.

Wiryadiputra. 2005. masalah Residu Pestisida Pada Biji Kopi Indonesia dan Antisipasi Penanganannya. Warta Pusat Penelitian Kopi dan kakao Indonesia, 21(3), 104-119 
Wijaya Suryani. 2004. Produksi Non-ICO Perparah Oversupply Kopi. Kopi Indonesia Jendela Informasi Perkopian. Disi 123/Th Xi/ November-Desember 2004.

Surono,I, Sudaryanto, Prawoto, 2004. Apa itu Pertanian Organik ?htt://blog.biocert or.id/2004/08/apa-itu-pertanianorganik.html.

Sudiarto, Gusmani. 2004. Pemanfaatan Bahan Organik In Situ Untuk Efisiensi Budidaya Jahe Yang Berkelanjutan. Balai Penelitian tanaman Rempah dan Obat. Jalan Tentara Pelajar No. 3. Bogor. Jurnal Litbang Pertanian. 23(2). 2004.

Widya, N. 2002. Pembuatan Kompos. Yogyakarta: UGM. http://nasih.staff.ugm.ac.id/p/009\% $/ 020 \mathrm{p}^{0} 20 \mathrm{k}$ $\underline{. h t m}$

Wayan R.Susilo. 2007. Standar OTA Eropa untuk Kopi Musuh Yang Konstruktif. : Bogor. Lembaga Riset Perkebunan Indonesia

Vicent G. 1994. Metode Perancangan Percobaan. Bandung.CV Armiko

Zimmerman, R.\&W.S. Cransshaw. 2001. Insect Parasitic Nematodes. Available at: http://www.ext.colostate.edu (2 Juni 2004)

Natawigena, H . 1987. "Hama hama Tanaman Perkebunan Rakyat dan Cara Pengendalian" dalam Laporan Penelitian Program S0. UNPAJ Bandung 